LITERATURA 



\title{
MÁSCARAS DE UNA IDENTIDAD OCULTA. UNA LECTURA DE "SEÑALES CAPTADAS EN EL CORAZÓN DE UNA FIESTA” DE RODRIGO FRESÁN ${ }^{1}$
}

\author{
Virginia Caamaño Morúa
}

\begin{abstract}
RESUMEN
Este estudio se enfoca en la manera en que la glocalización de la cultura se manifiesta en la historia personal del protagonista del cuento: un hombre inscrito en una sociedad latinoamericana del fin siglo, quien al narrar sus vivencias, construye y va mostrando aspectos de su propia biografía. La puesta en escena de ésta es acompañada por la presencia constante de elementos representativos de la cultura Pop, la cual se inspira en los aspectos más inmediatos de la sociedad de consumo, como los producidos por las tecnologías mediáticas y la publicidad. Pero además, en su intimidad, al reflexionar sobre sus vivencias y sentimientos y confrontarlos con las construcciones imaginarias mundializadoras, este personaje comprende su irremediable marginalidad, su propia diferencia, que le impide encontrar un sentido de pertenencia.

Palabras clave: Fresán- Rodrigo, literatura latinoamericana, glocalización, medios de comunicación y del entretenimiento, identidad gay.
\end{abstract}

\begin{abstract}
This study focuses on how glocalization is manifested in the personal history of the story's protagonist: a man living in an end of the century Latin American society, who, by narrating his experiences, construes and shows certain aspects of his own biography. The staging of this is accompanied by the constant presence of elements representative of pop culture, which is inspired by the most immediate aspects of the consumerist society, those produced by technology and advertising. However, in his intimacy, while reflecting on his experiences and feelings, as well as confronting them with his imaginary globalising constructions, the protagonist understands his unavoidable marginality, the difference that makes him unable to find a sense of belonging.
\end{abstract}

Keywords: Fresán- Rodrigo, Latin American literature, glocalization, media, gay identity.

Lo que hay detrás de una máscara nunca es un rostro. Siempre es otra máscara. Las máscaras son tú, y la máscara que hay detrás de la máscara también eres tú y así sucesivamente y con todas las cosas.

José Donoso en: Pilar Donoso (2009)

Esperando que un mundo sea desenterrado por el lenguaje, alguien canta el lugar en que se forma el silencio. Luego comprobará que no porque se muestre furioso existe el mar, ni tampoco el mundo. Por eso cada palabra dice lo que dice y además más y otra cosa.

Alejandra Pizarnik (1971)

M.L. Virginia Caamaño Morúa. Profesora Catedrática e investigadora en la Escuela de Filología, Lingüística y Literatura y en la Maestría de Literatura de la Universidad de Costa Rica.

Correo electrónico: vicaamano@yahoo.com

Recepción: 26- 06- 2012

Aceptación: 23- 08- 2012 


\section{Identidades y "glocalización" de las culturas}

El fenómeno conocido como "glocalización”, resultado de la correspondencia recíproca aunque desigual entre los procesos socioculturales y económicos globales con los locales, ha venido a modificar, irreversiblemente, todos los aspectos de la vida de las sociedades del planeta durante las últimas décadas. El término glocalización, utilizado por primera vez - de la manera en que ahora se entiende ${ }^{2}$ - por el sociólogo británico Roland Robertson (cfr. 2000) comprende también a los media ${ }^{3}$ que al atravesar las fronteras, han estimulado la asimilación de un enorme conjunto de imágenes y hábitos culturales anteriormente ajenos, los cuales han ayudado, en buena medida, a considerar el planeta como una totalidad. El mercado y su 'lógica' aparecen como componentes esenciales de la glocalización pues todo lo atraviesan, como advierte Daniel Noemí, “[...] No hay afuera del mercado y no hay nadie que pueda, realmente, posicionarse fuera del él” (2004: 36) ${ }^{4}$. En virtud de tales circunstancias, los imaginarios sociales se construyen desde dentro de esas corrientes culturales y económicas globales, lo cual viene a incidir, profundamente, en la transformación de las construcciones identitarias nacionales, locales e individuales.

Un análisis amplio y profundo sobre la glocalización es aportado por el antropólogo sociocultural indio Arjun Appadurai, quien considera que los flujos culturales que la componen crean comunidades que no tienen "sentido de lugar": "Ahora el mundo en que vivimos parece rizomático, incluso esquizofrénico; parece requerir, por una parte, teorías de carencia de raíces, alienación y distancia psicológica entre individuos y grupos, y, por otra, fantasías (o pesadillas) de cercanía electrónica" (Appadurai 2002: 15). Para estudiar la manera en que dichos fenómenos se presentan, propone examinar cinco aspectos de tales flujos culturales globales denominándolos: "etnopaisajes","tecnopaisajes","finanzopaisajes" "“ideopaisajes" y "mediapaisajes" (2002: 21). La relación entre los tres primeros aspectos mencionados conforman una especie de "infraestructura" global profundamente disyuntiva e impredecible, puesto que cada uno de ellos tiene sus propias limitaciones y a la vez limita a los demás. Los dos últimos, ideopaisajes y mediapaisajes, se refieren a la construcción y distribución de:

\footnotetext{
[...] imágenes, relatos y etnopaisajes en los que el mundo de las mercancías y el mundo de las noticias y la política están profundamente mezclados. Lo que esto significa es que muchos auditorios por el mundo experimentan los media mismos como un repertorio complicado e interconectado de impreso, celuloide, pantallas electrónicas y vallas anunciadoras. (Appadurai 2002: 24) ${ }^{6}$
}

Estudiosos como García Canclini y Martín Barbero entre otros, coinciden en señalar a los mediapaisajes - las tecnologías de la comunicación y del entretenimiento-como uno de los instrumentos fundamentales que permiten a las relaciones glocalizadas abarcar, de un modo u otro, prácticamente toda la vida de las sociedades del mundo. Los mediapaisajes han sido parte esencial en los procesos de desterritorialización y relocalización resultantes de las migraciones sociales y de las divisiones culturales y de clase en la vida en las ciudades actuales. Bajo su enorme influencia la gente se ha visto impulsada a consumir toda clase de productos, ideas, modas y costumbres en la construcción de sus propias identidades, transformando sus valores y sus estilos de vida.

Desde esa perspectiva, también es imprescindible observar cómo en los espacios culturales locales, la "recepción" de lo global es selectivamente apropiada y transformada, y así lo señalan varios autores. Appadurai lo llama indigenización de lo global (cfr. 2002), mientras Remedi lo ve como un tipo de nacionalización de los productos globales, realizado por las 
culturas locales (cfr. Remedi 2001). De ese modo, se explica que las identidades nacionales sean cada vez más multilingües, interculturales y transterritoriales, pues se constituyen a partir de múltiples transformaciones y mezclas de componentes procedentes de otras sociedades con la propia, destacándose, en ocasiones, el trabajo de nacionalización de los "consumidores", que hacen uso de los objetos según su propia manera de representación del mundo, la cual varía inmensamente de lugar en lugar y aún de persona en persona, resultando en una amplia diversidad de paisajes mediáticos.

\section{Paisajes mediáticos}

El proceso transformativo que la industria de la información ha experimentado, desde sus lejanos inicios con la imprenta y los periódicos, gracias al cual funciona como un poder ${ }^{7}$ globalizado ha llevado a que ya no se considere -como usualmente se creía- que los medios reflejan las realidades, sino que "[...] en cierta medida, las configuran" (Giddens 2000: 42), en función de su impacto en la vida cotidiana, al ser un fenómeno cultural cuya interiorización permite a la gente construir y dar sentido a sus vidas, como enseña Appadurai.

El estímulo de la información y las imágenes distribuidas por los medios, hace confluir una amplia red de experiencias en virtud de las cuales la gente se identifica a través de sentimientos de simpatía, tristeza, solidaridad o enojo, mientras les brindan espacios virtuales para relajarse y divertirse, fomentando la construcción de visiones de mundo y redes de información que conforman, en numerosas ocasiones, lo que Giddens llama el efecto collage. Este es el resultado de la presentación de un suceso, que ha sido comunicado e impuesto en la localidad a través de una "[...] yuxtaposición de relatos y materiales que comparten tan sólo su carácter ‘cronológico’ y secuencial” (2000: 41). El collage informativo aparece a menudo como una mezcla indiscriminada de noticias e imágenes de todo tipo, pues no existen criterios de jerarquización de acuerdo con la importancia que pudieran tener, presentándose como una especie de encrucijada donde se encuentran e incorporan múltiples textos, donde noticias sobre política, economía, sociedad, cultura, modas, espectáculos y sucesos provenientes de sitios lejanos se mezclan con los producidos localmente, difuminando su presencia antes dominante, al situarlos a todos "[...] en un mismo plano de equivalencia" (Cuadra 2003: 24). Esto ocasiona, las más de las veces, miradas superficiales, irreflexivas o confusas sobre los eventos informados y anula las relaciones de jerarquía entre la cultura elitista y la popular (cfr. Cuadra 2003).

Con base en lo señalado, no es de extrañar que los cambios producidos por los medios en América Latina sean más dramáticos, profundos y evidentes en las generaciones más jóvenes, pues han nacido y crecido en contacto directo con las tecnologías audiovisuales y las industrias del entretenimiento, que pasan de la televisión, el cine y la música, hasta el internet y demás redes de información, de acuerdo con sus posibilidades económicas y la situación de sus países, en función de las cuales construyen nuevas identidades multiculturales.

\section{Paisajes íntimos en las literaturas de la América Latina contemporánea}

Todos los fenómenos mencionados incitan a la reflexión sobre las vivencias experimentadas y son plasmadas en la literatura actual del continente, donde se hace efectiva la afirmación de Daniel Noemí quien propone que ya: “[...] no es posible sostener la existencia de ese campo 'mágico-mítico' que situaba al 'mundo de las letras' en un singular exterior, en una 'realidad' sin contacto con aquella otra, prosaica y mundana, de todos los días" (2004: 26). 
La formulación de conceptos que entrelazan lo global con lo local, llevada a cabo por Appadurai, facilita el acercamiento a los diferentes fenómenos que tienen lugar en sociedades mundializadas contemporáneas, como las latinoamericanas, y permitirá identificar su presencia y sus marcas en el abordaje del cuento: "Señales captadas en el corazón de una fiesta" $(1996)^{8}$ del argentino Rodrigo Fresán ${ }^{9}$. En ese relato su protagonista escenifica algunos de los cambios mencionados, pues se construye en función de representaciones cada vez más imaginarias, fundamentadas en un individualismo narcisista estimulado por los media y los mercados (cfr. Giddens 2000), cuyo desenlace ha sido, a menudo, la frustración, la desesperanza o la autodestrucción. Sobre todo por que, como señala el sociólogo británico Anthony Giddens, el espacio de la vida personal es uno de los ámbitos más agudamente afectados por la dinámica -o "dialéctica" de acuerdo con su propuesta- entre lo local y lo global, pues si la identidad del yo "[...] es el yo entendido reflexivamente por la persona en función de su biografía" (2000: 72), en la situación mundializada actual "[...] el yo alterado deberá ser explorado y construido como parte de un proceso reflejo para vincular el cambio personal y el social [...]" (2000: 49) ya que "[...] por primera vez en la historia de la humanidad, el 'yo' y la 'sociedad' están interrelacionados en un medio mundial" (2000: 48). En la literatura latinoamericana esto se manifiesta en la importancia que se le otorga a las micronarrativas, con su exaltación del individuo y sus historias íntimas y personales y no en la continuidad de un discurso identitario regional esencialista, establecido por la institución literaria.

Es muy evidente que los autores de las dos últimas décadas construyen sus proyectos escriturales a partir de una búsqueda personal inscrita en las circunstancias que han debido enfrentar, la cual pretende de muchas distintas maneras responder a la pregunta -planteada por Fuguet y Gómez en la introducción de su antología de cuentos McOndo (1996)_ “quién soy?". Esa búsqueda se muestra en este trabajo a partir del término "paisaje" -proveniente de las propuestas de Appadurai- referido a la intimidad de las personas inmersas en una situación de mundialización de las culturas, así como a las relaciones que puedan establecer en ese contexto, consigo y con los otros. Tales "paisajes íntimos" plasmados en las vivencias del protagonista del relato, se analizan a la luz de los aportes de Giddens (2000) sobre la identidad del yo, los cuales permitirán determinar el proceso de construcción del discurso identitario del personaje.

Según Giddens, en función del orden mundial actual, el yo se ha convertido en un proyecto reflexivo que parte de la necesidad de construir una narrativa biográfica - una historia de vida- con sentido propio, tanto en relación con las normas personales como con el contexto cultural y social, para encontrar un lugar de pertenencia. Por esto: “[...] a la cuestión “¿cómo he de vivir?", hay que responder con decisiones tomadas cada día sobre cómo comportarse, qué vestir, qué comer -y muchas otras cosas-; además, tal cuestión se ha de interpretar en el despliegue de la identidad del yo en el tiempo" (2000: 26). Para construir esa narrativa la persona deberá reunir las diferentes esferas de su vida, de tal forma que llegue a percibir una sensación de continuidad biográfica, la capte e interprete reflejamente; en otras palabras, debe desarrollar la capacidad para "[...] llevar adelante una crónica particular" (2000: 74), que le permita saber cómo ha llegado a ser lo que es, pueda sostener esa historia y comunicarla.

Desde ese punto de vista, interesa establecer la manera en que el protagonista del cuento, inserto en una sociedad glocalizada del fin de siglo, construye su narrativa biográfica. ¿De qué manera aparecen las inevitables marcas de la circulación cultural global en la particular vida del personaje? ¿Cómo lo afecta y procesa la presencia de ese fenómeno en su biografía? Es lo que se intentará determinar a lo largo de la lectura de la narración, inscrita 
en una literatura que ya no se atiene a la tradicional concepción -establecida a partir del siglo XIX- que la considera fundamento y manifestación de las identidades nacionales y regionales, en un momento histórico donde tales construcciones discursivas, excluyentes de una variedad de grupos y por lo tanto constructoras de estereotipos de la Otredad, parecieran ser obsoletas.

Los escritores latinoamericanos de las dos últimas décadas no responden a esa visión que suponía la utilización de la literatura como medio de denuncia de las circunstancias socioculturales y políticas que afectaran al continente. Ese deber-ser que se le ha asignado al escritor de la región es llamada por Rodrigo Fresán "el estigma de ser latinoamericano" (2004: 51), al imponérsele a los creadores ciertas condiciones en el ejercicio de su oficio, sin las cuales no tendrían cabida dentro de la institución literaria.

A pesar de la rebeldía manifiesta de los escritores del fin de siglo ante las imposiciones de la crítica canonizante y de las editoriales, ella no impide que demuestren conciencia de las situaciones sociales, económicas y culturales que afectan a las sociedades de las que provienen, pues a pesar de su rechazo a ser leídos en virtud de un supuesto contexto "real" -a menudo estático, construido unidimensionalmente y sustentador del prejuiciado "macondismo"10_ sino desde un acercamiento que privilegie sobre todo lo estético-literario, no pueden dejar de inscribirse en el tiempo histórico que les ha correspondido vivir, lo cual se evidencia en la rica variedad de sus propuestas literarias. Precisamente, por su conciencia de las corrientes hegemónicas que prevalen es que denuncian a la cultura letrada y dentro de ésta a la institución literaria como "[...] un negocio que cada día exige más imagen, diseño y publicidad, y bastante menos crítica, creación y conocimiento" (Iwasaki 2004: 111) y deben ceder ante ciertos parámetros impuestos, para no ser desechados por el mercado editorial que está en manos de grandes conglomerados, a los cuales sólo los guía la búsqueda del beneficio económico. A fin de cuentas, como afirma Noemí: “[...] Toda literatura habla del mercado, es conformada por éste y al mismo tiempo le da forma” (2004: 199). Así, aunque algunos escritores intenten rechazar la lógica mercantil y quedar fuera de ella, “[...] ser el otro [...] respecto del mercado, [...] indefectiblemente pasa a constituir y conformar un modo otro de hablar del mercado, desde el mercado mismo" (Noemí 2004: 200).

De acuerdo con lo expresado, este estudio se enfocará en la manera en que la glocalización de la cultura se manifiesta en la historia personal de su protagonista: un hombre inscrito en una sociedad latinoamericana del fin de siglo, quien al narrar sus vivencias, construye y va mostrando aspectos de su propia biografía como nadie más lo podría hacer, confirmando la propuesta de los intelectuales inscritos en las corrientes subalternistas, quienes afirman que no se puede hablar por los demás ${ }^{11}$.

\section{Imaginarios excesivos, abrumadores}

El país en que ocurren los sucesos narrados en el relato es identificado por referencias a sitios y sucesos que lo representan ${ }^{12}$. Su personaje muestra un estilo de vida particular, propio de estratos medios o altos de su sociedad, los cuales se imbrican con visiones de mundo provenientes de distantes lugares del planeta: etnopaisajes, mediapaisajes e ideopaisajes, hijos de la globalización, cuyo consumismo es característico de las sociedades más ricas.

La puesta en escena de la historia del protagonista es acompañada por la presencia constante $-\mathrm{y}$ a veces excesiva- de elementos representativos de la cultura Pop, la cual se inspira en los aspectos más inmediatos de la sociedad de consumo ${ }^{13}$, sobre todo, los producidos 
por las tecnologías mediáticas y la publicidad. Pero además, en su intimidad, al reflexionar sobre sus vivencias y sentimientos y confrontarlos con las construcciones imaginarias mundializadoras, dicho personaje se ve en la necesidad de negociar con una realidad inefable, que lo lleva a vislumbrar su irremediable marginalidad, su propia diferencia, impidiéndole encontrar un sentido de pertenencia. Durante su recorrido por ese camino, también actualiza y pone a circular en el texto discursos provenientes de diversas corrientes reflexivas, compañeras de la humanidad en sus intentos por dar respuesta a las inquietudes que cada época convoca. Juntos en una abigarrada mezcla, los elementos mencionados ocupan el escenario del relato, dificultando la aprehensión del argumento fundamental de la historia.

\subsection{Un laberinto literario}

A partir de lo explicado arriba, "Señales captadas en el corazón de una fiesta" se construye como un texto-collage, donde "[...] la manía referencial: las citas y los guiños constantes" (Cristoff $1998^{14}$ ) que el autor reconoce en su literatura, aparecen en virtud de una considerable yuxtaposición de discursos y productos, procedentes de diferentes sitios y prácticas culturales: música anglosajona de la década de los años ochenta; temas y personajes literarios; escritores de novelas; películas, actores y directores cinematográficos; personajes míticos y de la cultura pop; hechos sucedidos, modas de toda índole... en un claro ejemplo de apropiación de representaciones culturales globales -podría decirse que su "glocalización"- con cuyas imágenes fragmentadas y en función metafórica se construye una estructura laberíntica que sostiene la historia de vida del protagonista.

Un laberinto cuya esencia, de acuerdo con Leonardo Da Vinci, se encuentra en "[...] circunscribir en el espacio más pequeño posible el enredo más complejo de senderos y retrasar así la llegada del viajero al centro que desea alcanzar" (citado en Chevalier 1995: 620). Dicho "enredo" es fabricado en el relato con las múltiples imágenes y productos derivados de los media, presentados como obstáculos -digresiones- ante los cuales quien lee debe prestar atención para no perder las pistas que el narrador va mostrando, en un viaje iniciático durante el cual ambos, lector y narrador, marchan en busca del centro, para encontrar la clave del cuento. Esta última puede interpretarse también, a la luz de lo señalado por Chevalier, como uno de los simbolismos del laberinto: el camino hacia el interior de sí mismo, donde se encuentra lo más oculto de la persona, su inconsciente, el cual sólo será alcanzado "[...] tras largos rodeos o una intensa concentración hasta esa intuición final donde todo se simplifica por una especie de iluminación. Allí en esa cripta, se vuelve a encontrar la perdida unidad del ser, que estaba disperso en la multitud de sus deseos" (1995: 621-622). Siguiendo la propuesta de Chevalier, la "cripta" mencionada podría homologarse con el relato, pues en él se han depositado, por medio de la escritura, las imágenes metafóricas representativas de las diversas máscaras tras las cuales se ha fragmentado el narrador, ocultándose ante el temor de dar a conocer su verdad. Hace efectivo el significado que el Diccionario de la Real Academia le asigna, en su primera acepción, al término máscara, como una "[...] figura que representa un rostro humano, de animal o puramente imaginario, con la que una persona puede cubrirse la cara para no ser reconocida". La verdad que teme mostrar se hace evidente cuando el narrador termina su recorrido autobiográfico: al juntar todas las imágenes se atreve a descubrir-se y lo enseña a quien lee. Realiza durante su viaje un itinerario reflexivo, indispensable según afirma Giddens, para componer una crónica particular que le permite construir su autoidentidad. Por otro lado, 
el simbolismo del viaje también se actualiza cuando le permite al protagonista buscar la verdad, su verdad, la cual muestra que su vida estuvo marcada, en un juego de ausencia-presencia de la figura materna, por dos tendencias paradójicas: por una parte, el deseo de encontrar a su madre perdida -como propone Jung- o, por el contrario, por la necesidad de huir de su madre -como sugiere Cirlot- (cfr. Chevalier 1995: 1065-1067). La función que la imagen de la cripta desempeña es también paradójica, pues como depositaria de todas las máscaras y facetas que componen al narrador, finalmente le da unidad a su ser, pero ese mismo descubrimiento lo impulsa a no ser, a buscar la muerte.

La muerte, ese "[...] momento en que el control humano sobre la propia existencia encuentra su límite extremo" (Giddens 2000: 206), es introducida desde el incipit por una voz narrativa masculina y anónima, como uno de los temas fundamentales sobre el cual se reflexiona a lo largo del texto, cuando se dice que las señales del título son "[...] metálicas y frías y monocordes [...]. El derrotado himno de batalla, la triunfante marcha fúnebre” (Fresán 1996: 33) ${ }^{15}$. El juego de palabras donde la oposición planteada en los adjetivos es aclarada por los sustantivos sugiere, desde el discurso musical, que la batalla se ha perdido antes de empezar, pues la muerte siempre triunfa. Se dice que Willi, uno de los personajes del cuento "[...] ya llevaba dentro el germen de su muerte" (50-51) -como todos los seres humanos- de la misma manera en que Borges, siguiendo a Schopenhauer, afirma que ella "[...] es patrimonio exclusivo de los vivos" (45). Se anuncia así, desde el principio del cuento, su final de muerte.

El monólogo discursivo de la voz narrativa, enunciado a través de frases largas y "[...] oraciones en serpentina con altibajos y curvas" (Cristoff 1998), es como un abigarrado rompecabezas, compuesto por una rápida enumeración de series de cosas, personajes, nombres y sucesos, que en el momento en que son dichos, se hacen presentes performativamente y explican su razón de ser en su función misma de metáforas y símiles, las cuales permiten la construcción de la historia. De acuerdo con ese discurso, el cuento puede leerse en tres partes, donde parecieran actuar dos personajes. Durante la primera, el narrador-protagonista anónimo habla en primera persona sobre las fiestas, la música y ciertas características de quienes asisten a ellas. Comenta además, por medio del flash-back puntual, los cambios que han sufrido con el paso del tiempo, tanto las fiestas como la gente. El mediapaisaje establece en esta sección su presencia dominante.

En la segunda parte el narrador cuenta cómo Willi, su pareja, quien "creía en Dios y le indignaba su desaparición" (52), padecía del "horror de creer" (52) y para atraer la atención de ese Dios ausente, se entrega a la homosexualidad "[...] como algunos científicos se entregan a determinada especialización con el propósito de dominarla y hacerla definitivamente suya” (53). Willi, quien ha muerto de sida, sentía remordimiento por sus preferencias sexuales, mientras el narrador, por el contrario, afirma nunca haberlo sentido al comentar sarcásticamente: "Gracias a Dios soy ateo" (54). Así, a lo largo de esta sección y empleando de nuevo el flash-back, el protagonista habla sobre Willi y cuenta lo que éste pensaba, leía y decía. Hasta aquí, la imagen de un hombre en duelo por la muerte del ser amado es lo que el texto escenifica.

En la tercera parte, clímax y final del relato, el protagonista expone, por medio de un discurso confesional, su paisaje íntimo, su verdad: Willi y él son la misma persona. Él es Willi y ha inventado al narrador; así ciertos atributos y acciones que el protagonista ha contado sobre sí, en una fragmentada y difusa descripción, son propias de Willi, el verdadero narrador. El falso narrador anónimo, un narrador no fidedigno que ha engañado al lector desde el inicio, ha adjudicado a su 'otro yo', Willi, algunas ideas y conductas que le habría gustado tener a 
éste, pero en su mayoría, son inventadas desde el deseo. En la lógica del cuento, ficción dentro de la ficción, ambos ‘yo' son parcialmente reales y parcialmente ficticios. Los dos actúan de maneras en que el 'verdadero Willi', el narrador de la tercera parte, nunca se atrevió. Ambas invenciones le permiten imaginarse -vivir virtualmente a través de la escritura- lo que habría sido su vida si se sumaran sus historias, tal y como propone Freud, quien señala como una de las variaciones del tema del doble "el desdoblamiento del yo", el cual incorpora:

\footnotetext{
[...] todas las posibilidades de nuestra existencia que no han hallado realización y que la imaginación no se resigna a abandonar, todas las aspiraciones del yo que no pudieron cumplirse a causa de adversas circunstancias exteriores, así como todas las decisiones volitivas coartadas que han producido la ilusión del libre albedrío. (1981: 2494)
}

Así, en esta tercera parte, en una vuelta de tuerca, el Willi real, desde el tiempo presente del relato, cuenta su historia real, donde expone su miedo a amar a otro hombre. Miedo que surge como una consecuencia del cristianismo: cree en Dios, teme su castigo e inclusive llega a proponer que en su identidad sexual tal vez esté su castigo, su maldición, pues lo destinó a la soledad y la desesperanza. Y acude al antiguo tema del pecado original para sugerir que, desde el comienzo, este marcó su vida. Su castigo es provocado por el adulterio materno, descubierto y filmado por el padre en la fiesta de su nacimiento, primera y única que se le dedica. A partir de ese hecho, el relato se convierte en un "viaje a la semilla"16 donde el principio es el final y el final el principio, ocurrido todo durante sendas fiestas: narrada desde su presente, a los sesenta años de edad cuando está a punto de morir, se remonta hasta la confesión sobre dicho "pecado original”, en una búsqueda por darle sentido a todo lo vivido. La figura de Willi es construida desde los márgenes del paradigma occidental: como hombre gay latinoamericano, aún en su propia sociedad y en su círculo inmediato, es marginal -o se automargina- a tal punto, que se autodesigna como "el hombre invisible", desde una visión fatalista de la existencia.

Los hechos contados podrían explicar su dificultad para construir su biografía; su identidad confusa, puesto que su padre podría no serlo realmente - ¿lo será el amante de su madre?-, tal vez por eso nunca se dice el apellido del narrador y su nombre aparece hasta la tercera parte de la historia, cuando confiesa que es Willi. Como hombre gay, no se atreve a reconocer y actuar libremente su identidad sexual y a buscar el amor, lo cual implicaría enfrentar -siguiendo a Foucault (cfr. 2002)- la voluntad de verdad establecida y sufrir la estigmatización de su condición. La vida que ha escogido vivir, desde lo dicho, es de una soledad extrema: las relaciones familiares no existen debido a la ausencia emocional de la madre y al rechazo solapado del padre y no se habla de amistades cercanas; tampoco se aclara su ocupación en ninguna parte del relato; de todos modos, su posición socioeconómica pareciera no obligarlo a trabajar, su único oficio es "observar" y juzgar las fiestas. Un modo de vida puesto en cuestión a lo largo del texto, pero sobre todo al final, en su última fiesta, cuando explica que el suicidio es la salida encontrada para cerrar de una vez ese paréntesis vacío que ha sido su existencia inútil.

Pero aún desde ese último momento sigue contando sus vivencias al lector, para que este dé algún sentido al camino recorrido. Con ese fin el narrador capta, separa y ordena las señales de la fiesta -imágenes que han definido su vida-, metafóricamente las aprisiona en una botella $^{17}$-que es el relato- y las lanza al espacio, con la esperanza de que sean recogidas y también "captadas". Tales señales como metáfora de la escritura ordenarán su biografía y al ser leídas, se conocerá su historia; quien lea puede apreciar si lleva razón cuando al final, pleno de conmiseración consigo mismo, el protagonista se compara de dos maneras con los astronautas rusos, que se ha dicho, están perdidos en el espacio. Primero, al hacer un paralelismo con el 
niño recién nacido que fue él, de repente lanzado -en su cuna- al espacio de la duda sobre su origen y con ella, al desamor y luego, al mostrar la forma en que se ha mantenido, desligado de todo y de todos, como si viviera dentro de una cápsula espacial. Con determinismo existencial afirma que desde el inicio de su camino nunca tuvo posibilidades para vivir la vida como habría querido hacerlo: no pidió nacer, arrojado al mundo y abandonado, sólo se ha dejado llevar pasivamente por su destino, sin oponer resistencia. Convoca así a la reflexión de quien lee sobre la pertinencia de sus conclusiones, pues muestra un narcisismo marcado al no asumir la responsabilidad por el rumbo que dio a su vida, característica mencionada como una de las más extendidas entre las personas que viven en las sociedades mundializadas de la actualidad.

\subsection{Un espacio virtual con habitación de los abrigos}

Las fiestas, sitio de reunión donde la gente celebra algún suceso o simplemente se divierte $^{18}$, brindan el espacio donde transcurre la historia: fiestas desde el principio -en el título- hasta la conclusión. Fiestas que sirven como "[...] cultivo representativo y desconcertante pero siempre esclarecedor de un determinado tiempo y espacio" (43-44) y son propuestas como génerico que las incluye a todas ellas. Las fiestas desde esa perspectiva, son un espacio virtual más que material, cuya presencia se hace concreta a partir de su comparación con una bestia indomable, con una planta que crece desordenadamente, con una epidemia, porque "[...] el mundo verdadero ocurre dentro de una fiesta" (40). Son concebidas como radiografías de la época, pues al volver a ellas -para leerlas desde la distancia que brinda el tiempo transcurridose podría saber la visión de mundo predominante entre quienes las han celebrado, por la forma en que lo hacen y por la música que escuchan. Y eso propone hacer el texto: mensaje virtual materializado, que guía por los vericuetos de las fiestas y de las vidas que las festejan en medio del barullo, siguiendo el camino que marca el narrador, mientras su mirada, como la de un voyeur a la distancia, se posa sobre los festejos y sus celebrantes.

Para mostrarlas, el narrador ha separado las celebraciones en dos categorías, de acuerdo con el tiempo en que ocurren: el presente de la narración y los años ochenta. Yendo y viniendo en el tiempo, recoge "las señales que capta en el corazón" de la fiesta a la que asiste en el presente y las compara con las de su juventud en los años ochenta: "La Era Antes de Rock" (38) -antes de la muerte de Rock Hudson-, donde gente como él -"los exquisitos marginados"- va de fiesta en fiesta, vive sólo para ellas como "[...] una criatura de la noche" (38). Las fiestas actuales reciben su dura crítica, son envasadas al vacío, realizadas por gentes demasiado jóvenes, en casas demasiado grandes e iluminadas: sus señales no le dicen nada. Sin embargo, en todas las fiestas sin excepción hay un sitio fundamental en la organización estratégica del texto: la "habitación de los abrigos" (56), que es "[...] el corazón exacto de una fiesta" (54) y es descrito por Willi con las características de un laberinto, al ser "[...] El sitio exacto donde se unen y se encuentran todas las rectas y los comportamientos torcidos" (54). Ubicada al fondo de la casa donde se da el festejo, guarda los abrigos de los invitados y representa el centro del laberinto, lugar donde ocurren los principales hechos de la vida del narrador. En una habitación así, la madre en compañía de su amante es descubierta por el padre; en otra parecida irá a refugiarse el agonizante Willi, para morir escondido debajo de los abrigos, tal como vivió, oculto en medio del ruido.

Existe cierto paralelismo entre el volumen de los abrigos y la acumulación de información, tan profusamente suministrada en el texto, la cual hay que apartar para ver lo que oculta debajo. Como harán los invitados en la última fiesta de Willi, cuando al recoger sus abrigos lo encuentren enterrado bajo ellos, sin vida: 


\begin{abstract}
Empujo la montaña de abrigos a un lado como si separara las aguas del mar Rojo. Me acuesto en la cama. En el centro justo, en el cálido canal lleno de abrigos. Suspiro y, con un último esfuerzo, me voy cubriendo de abrigos como si fueran capas de tierra, como si me fuera convirtiendo en un fósil prisionero de cortes geológicos. (56)
\end{abstract}

Desde esta interpretación, la habitación aparece como el hilo que guía hacia lo esencial y aparta de los confusos caminos por los que el laberinto informativo pareciera llevar, pues como advierte García Canclini: "El riesgo es que el viaje digital errático sea tan absorbente que lleve a confundir la profusión con la realidad, la dispersión con el fin de los poderes y que el encandilamiento impida renovar el asombro como camino hacia otro conocimiento" (2009: 22). Para llegar a dicho conocimiento la lectura se enfocará entonces en el protagonista y su biografía a partir de los múltiples productos culturales que son parte del barullo que lo rodea. Ellos actúan también como metáforas que otorgarán sentido a los acontecimientos contados por el "último de los party-animals” (37) y guiarán a quien lee hacia el centro, iniciando con la música que lo acompaña y define.

\title{
4.3. La banda sonora
}

La letra de las canciones y la mención de sus intérpretes convoca el tiempo hacia el cual la voz narrativa viaja en su memoria, organizando su recorrido alrededor de una banda sonora en la que se nombran diversas canciones -populares en la década de los años ochentacuyos títulos y letras se centran en las fiestas: "All Tomorrow's Parties"19, "Party Line"20, "There's a Party at My House"21, "Left to My Own Devices" 22, "Fiesta"23. Las composiciones musicales, convocadas por la voz narrativa con nostalgia, incluyen piezas de grupos como Velvet Underground ${ }^{24}$, The Kinks ${ }^{25}$, The Pet Shop Boys ${ }^{26}$, Talking Heads ${ }^{27}$ y aún The Beatles $^{28}$, los cuales prestan las "[...] palabras ajenas y las canciones cómplices" (35), que le ayudan a reconstruir su biografía, señales que capta quien lee. Los recuerdos van del presente de la narración -su última noche- a un momento de su pasado que abarca de mediados de 1982, cuando está por concluir la Guerra de las Malvinas ${ }^{29}$, hasta el 2 de octubre de 1985, fin de una época de festejos, clausurada por la muerte del actor hollywoodense Rock Hudson. La alusión a la Guerra y a uno o dos sitios (al Club San Isidro (57), por ejemplo), permite ubicar la historia en algún lugar de Argentina (¿Buenos Aires?), en círculos sociales muy acomodados -al menos de clase media alta-, por lo demás, los hechos podrían haber sucedido en algún otro sitio de Occidente.

Pero es la muerte de Rock Hudson la que introduce en el texto una de las más relevantes reflexiones existenciales en el paisaje íntimo del protagonista: el ocultamiento y la marginalidad provocadas por su orientación sexual alternativa, dentro de una sociedad que ha establecido como voluntad de verdad la práctica universal de la heterosexualidad obligatoria, así como la idea del castigo, representado por el virus del sida, el cual cierra "[...] el capítulo del amor y de la sexualidad que se había abierto, con música de rock y baladas, en los años sesenta" (Sarlo 1996: 24). En su artículo sobre el cuento en estudio, el crítico Henri Billard señala dos etapas diferenciadas en función de la presencia de la muerte representada en el virus y cómo a partir de éste, el protagonista busca vivir otras experiencias:

Recordemos que para los hombres y mujeres homosexuales latinoamericanos las fiestas privadas de los años 80 constituían uno de los pocos espacios donde divertirse, besar a su pareja, y en muchas ocasiones encontrar un compañero sexual sin censuras ni temor. Risas, miradas de deseo y libertad eran los ingredientes superficiales de estos espacios nocturnos. Sin embargo, bajo esa superficie yacía un hondo 
anhelo de intimidad, de comunión con un otro, de aceptación y de reciprocidad, con miras a compartir la propia vulnerabilidad. (2006: 62-63)

Explica así que las fiestas de los party-animals se realizaran en espacios privados, para evitar la injuria que la exposición de su identidad sexual les depararía, donde "[...] aquellos exquisitos marginados" (38) pudieran ser ellos mismos e interactuar libremente, sin temor a la estigmatización (cfr. Eribon 2001).

La presencia de la banda sonora cuyo tema central son las fiestas, sirve de sostén al discurso del protagonista, con el cual construye un mediapaisaje para describirse a sí mismo, especialmente, a partir de la letra de la canción "Left to My Own Devices"30, de The Pet Shop Boys, de la cual rescata un conjunto de características con las que se identifica, entre ellas, una infancia solitaria y triste y un presente en que sólo le interesa ir de fiesta en fiesta. Se declara con ella un 'party-animal' y como tal define su vida en tres etapas, en función de las fiestas a las que ha asistido. La primera etapa, durante su adolescencia, es la prehistoria, cuando apenas está empezando a asistir a ellas y nadie lo conoce. La tercera, a la que llama "el invierno", similar a la primera etapa, es descrita como una "falsa y patética infancia" donde "el hombre invisible" no es conocido ni recordado y ningún lugar es el suyo, es el presente del relato y sugiere una triste y anticipada vejez. La segunda etapa es la que vive en los años ochenta, cuando va de una fiesta a otra y recuerda con placer y nostalgia pues todos lo conocen y le asignan "[...] tareas de responsabilidad o riesgo, como, por ejemplo, llenar las copas de champagne o salir a buscar más cocaína [...]” (41).

La voz narrativa construye su identidad a partir de la música, pues desde lo que describe como su "ínfima tragedia" (34) de ser inexistente, las letras de las canciones le brindan una narrativa a partir de la cual puede ser. Coincide con el musicólogo británico Simon Frith, quien propone que música e identidad son: “[...] a la vez una interpretación y una historia, describe lo social en lo individual y lo individual en lo social, la mente en el cuerpo y el cuerpo en la mente; la identidad, como la música, es una cuestión de ética y estética" (1996: 184). Pues la música interpela a las personas de un modo más intenso que otros medios -la televisión o el cine- y las ayuda a entenderse mejor como seres históricos, étnicos, genéricos y de clase social (cfr. Frith 1996).

La banda musical del cuento se inscribe dentro del género Pop que agrupa -cierto tipo de música ligera y popular derivado de estilos musicales negros y de la música folclórica británica- ${ }^{31}$, combinación de géneros musicales que se empieza a popularizar a partir de los años cincuenta del siglo XX. De acuerdo con Frith, los musicólogos académicos no la consideran arte sino más bien un negocio pues afirman que es establecida -desde arriba-, por las compañías discográficas. Muchas de las imágenes e ideas propuestas en las letras del rock y en los videos, los jóvenes las “[...] consideran completamente propias" (Sarlo 1996: 115) y los estimulan a identificarse con los intérpretes, las letras de las canciones y las gentes que comparten su gusto. Por su medio, logran expresar modos de ser que los satisfacen emocionalmente y con los cuales crean una especie de autodefinición que les brinda un sentimiento de pertenencia, les otorga un sitio en la sociedad (cfr. Frith 1996). Sentimiento que ya no encuentra el protagonista en las fiestas del presente del relato y que le lleva a presentar otras facetas de su biografía con la ayuda de diferentes productos mediáticos.

\subsection{Una biografía fantástica}

Los títulos de algunas películas que circulan en el texto permiten la interpretación de ciertas experiencias de la voz narrativa, a partir del paralelismo entre sus historias. Por 


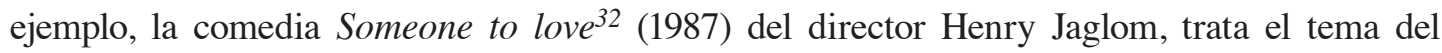
amor y la soledad y simula ser un documental. Para realizarlo, el director reúne a sus amigos con el fin de interrogarlos, mientras filma a cada uno. En medio de la fiesta, hablan sobre sus ideas y experiencias amorosas y reflexionan sobre por qué la vida no resulta como cada quien espera, estableciendo la necesidad de encontrar "alguien a quien amar". La historia de vida del protagonista podría reconstruirse a partir de ese film, ya que su padre también hace una especie de documental cuando filma la fiesta de su nacimiento. Abre y cierra puertas mientras, con la cámara, recorre el interior de salones y habitaciones hasta llegar a la habitación del fondo, la cual representa el centro del laberinto y como tal enseña lo que antes se encontraba oculto: la verdadera naturaleza de los sentimientos de su esposa hacia él, al sorprenderla en abrazo apasionado con el amante, disfrazado de "Gato de Cheshire"33. "[...] No ocurre nada entonces. No hay sorpresa en los ojos de mi madre. Menos aún el clímax de la súbita presencia de un revólver vaciándose de fuego sobre los cuerpos encendidos de los amantes. No ocurre nada" (59). La madre no se da cuenta de la presencia del padre y éste concluye la filmación, guarda la cinta y a su muerte "[...] en su tan generoso como despótico testamento" (59) se la hereda a su único hijo, que a sus sesenta años se explica, finalmente, el desapego de su progenitor hacia él, así como la relación fría y distante entre sus padres. Una corta alusión a su madre, definida por el “[...] atractivo pecado de sus perlas y de sus trajes brillantes" (59-60), señala la ausencia emocional de ésta en su vida, ocupada en su propia búsqueda de emociones y placeres sensuales. Ella, "hacía ya tiempo [...] se había recluido por su propia voluntad en una mansión para gente que ya no sabe como operar el manual de instrucciones de un mundo que los ha dejado de lado en busca de carne más joven y de sonrisas más ágiles" (59). Esta conducta materna es acreditada por el narrador como el origen de su desgracia y hace innecesarias más explicaciones sobre la falta de amor en su vida familiar. Ante la ausencia de esos lazos de afecto que son de importancia fundamental en el desarrollo del niño -al permitirle construir historias compartidas, para adquirir confianza en sí mismo y en los demás y así poder establecer vínculos íntimos en su vida posterior (cfr. Giddens 2000) - Willi no logra establecerlos en su vida adulta, por eso no cree en sí mismo ni en nadie más y su identidad es constituida por muchas facetas falsas, en una búsqueda de "alguien a quien amar". De ahí que el recorrido para armar su narrativa biográfica sea tan tortuoso -el camino laberíntico hacia su interior- y sólo lo logra al plantear la metáfora de la escritura -su 'autobiografía' (cfr. Giddens 2000)-, las señales lanzadas al espacio para que alguien las capte.

Otro film, sugerido apenas al decir "Bailábamos como en esos concursos de resistencia donde el detenerse por un par de segundos equivale a la descalificación o al tiro de gracia en el flanco de caballos quebrados" (39), es They Shot Horses, Don't They ${ }^{34}$ (1969), del director Sidney Pollack ${ }^{35}$, el cual interesa comentar pues introduce en el texto el tema del suicidio. La trama de la historia es ambientada durante la época de la Gran Depresión en los Estados Unidos, y se establece a partir del flashback. Gloria, la protagonista, ha tenido una existencia dura y solitaria y no desea seguir viviendo. Sin embargo, no se atreve a quitarse la vida y así lo cuenta a Robert, su compañero de baile en el concurso de resistencia. Luego de una serie de acontecimientos donde la mujer confirma que ya no puede esperar nada bueno del futuro, le pide a Robert que la mate y éste lo hace, por lo que es encarcelado y juzgado. Al explicar al juez las razones de su crimen, Robert dice que a los caballos malheridos, cuando ya no es posible salvarlos, los matan con un disparo para acabar su sufrimiento; Gloria era como un caballo herido y él tuvo piedad de su dolor. Igual que Gloria, Willi se presenta herido 
de muerte. La voz narrativa pareciera preguntarse, con Robert, si es permitido matar a los caballos, ¿por qué no se tiene similar compasión con las personas?

Como parte del mediapaisaje del texto, el protagonista también hace mención de directores cinematográficos como Jim Jarmusch ${ }^{36}$ y Tim Burton $^{37}$, o de actores como el citado Rock Hudson, Montgomery Clift y Peter Sellers ${ }^{38}$. Con estos últimos continúa la tarea de utilizar voces ajenas para establecer puntos de contacto en el recorrido por aspectos de su vida, pues tanto Montgomery Clift ${ }^{39}$ como Rock Hudson ${ }^{40}$ (1925-1985) mantuvieron oculta su orientación sexual de hombres gay, para no perjudicar su carrera como galanes en los escenarios hollywoodenses, viviendo una vida falsa que sólo les procura infelicidad. Dicha falsedad es análoga a la vivida por el Narrador-Willi y el paralelismo se refuerza con la ficción de la muerte de este último como víctima del virus del sida, igual que Hudson. El simulacro de vida que vive este actor está en consonancia con la que relata el narrador antes de confesar que es Willi. Por otro lado, el nombre de Peter Sellers, actor cómico reconocido por su falta de humor en la vida real, es el seudónimo que utiliza Willi para firmar alguno de sus poemas, lo cual termina de exponer la oposición entre el parecer y el ser de acuerdo con las características de vida tanto del narrador como de todos los actores mencionados y que involucra, además, al propio relato, donde en un inicio parece contarse una historia que en realidad termina siendo otra.

Para afirmar aún más la categorización del cuento como texto-collage, en cuya construcción se traslapan asuntos que conducen siempre a la historia personal del protagonista, se menciona de modo rápido y superficial una larga serie de 'cosas', de 'cuadros' -como si se tratara de imágenes siendo sustituidas por otras imágenes por medio del zapping- que se van sucediendo a lo largo del texto y abarcan desde una guerra con víctimas infantiles en Africa a una "postal" de hierros retorcidos, "[...] osamenta erosionada de un animal que alguna vez fue un automóvil" (34) los cuales lo representan a él, pasando por organizaciones caritativas internacionales que no le tenderían la mano, hasta llegar a las descripciones de las fiestas de la actualidad. Estas incluyen alusiones a la moda grunge; el uso de la cocaína y la marihuana; el estilo de vida New Age, el yoga y la lectura de libros de "autoayuda"; los fantasmas, el espiritismo y la Ouija; así como menciones a Santa Claus, Stonehenge, el Titanic y Versailles, para alcanzar a las generaciones 'posmodernas' del fin de milenio llamadas “irrealistas virtuales "[...] a quienes nada les interesa porque nada les preocupa" (42); en un constante fluir que obliga a quien lee a "[...] encontrar una posición, dentro de la multitudinaria interculturalidad, que conduzca a la autonomía y no al autismo”, como señala García Canclini (2009: 130).

La utilización de la figura del doble -tan presente en la literatura de todos los tiempos ${ }^{41}$ - adoptada desde el inicio por la voz narrativa-Willi como estrategia para contar su historia, continúa apareciendo como un elemento esencial en la integración del paisaje íntimo imaginario del protagonista, en su anhelo por construir una narrativa de vida que le permita ser y lleva la lectura hacia los lugares más profundos de aquella. Surgen entonces personajes literarios, mitológicos y reales cuyas características e historias permitirán al narrador continuar estableciendo analogías para hablar de él mismo y hacer comprensible su narración.

El primero en ser nombrado es Sísifo, figura destacada en el relato pues fundamenta una visión de mundo muy particular y sostiene la decisión final del narrador. Según el mito, como hombre astuto y tramposo ${ }^{42}$, Sísifo engaña a los dioses, quienes lo castigan de un modo terrible: debe empujar una roca hasta lo alto de una empinada colina, pero cuando logra llegar a la cumbre, la roca se le escapa y vuelve a caer. Sísifo debe llevarla de nuevo hasta arriba para recomenzar el ciclo y hacerlo así por toda la eternidad (cfr. Garibay 1971: 219-220), en 
una labor sin sentido ni finalidad alguna. El nombre de este personaje es el que se autoasigna el Narrador-Sísifo, cuando captura las señales para meterlas en la botella, culminando en la escritura del cuento, de manera que al ser leído induzca a la reflexión de quien se pudiera ver plasmado en el texto; aunque cabría preguntarse ¿será esa una labor inútil, si no es acatada como advertencia?

Pero además del intertexto mítico, es más significativo el filosófico-literario, establecido con El mito de Sísifo (2008), de Albert Camus, en su propuesta sobre el sentimiento del absurdo. Este es definido como: "Ese divorcio entre el hombre y su vida, el actor y su decorado [...]" (2008: 16) y sintetiza la manera en que el narrador del cuento analiza su biografía. Sentir el absurdo es ser permanentemente consciente de la inutilidad de la vida, sentirse incapaz de entender el mundo y permanecer siempre consciente de esa incomprensión. Todo comienza con esa conciencia y cuando se alcanza el despertar definitivo "[...] llega, con el tiempo, la consecuencia: suicidio o restablecimiento" (2008: 25). Camus deja claro que el sentimiento del absurdo, el saber que la vida no tiene sentido, no implica, necesariamente, decidir que no vale la pena vivir. Desde este estudio, puede verse cómo el protagonista plantea todo su recorrido autobiográfico y en función de sus diferentes facetas construye su narrativa, su historia, donde se manifiesta el sentimiento señalado por Camus como absurdo: ese extrañamiento entre él y su vida que lo llevará al suicidio, con el cual concluye el relato. El suicidio -único "problema filosófico realmente serio" (Camus 2008: 13)- resuelve el absurdo cuando la persona ya no puede enfrentarlo con plena conciencia y rebelarse. Rebelión que Sísifo sí logra. Justo en el momento en que la roca se desliza cuesta abajo y él desciende de nuevo a encontrarla para recomenzar el ciclo, es absolutamente consciente del absurdo: conoce su destino y lo cumple, pero se rebela en su interior al no manifestar resignación. Por eso Camus salva a Sísifo del suicidio. No es lo que sucede con el narrador, quien no tiene el odio a la muerte de Sísifo pero sobre todo, no ha tenido su pasión por la vida. A pesar de haber logrado acumular la mayor cantidad de experiencias posibles, que le darían posibilidades para no renunciar al absurdo, sólo las ha vivido en su imaginación, virtualmente, por medio de sus dobles y sus diferentes máscaras, a las cuales da vida en la ficción literaria -sus 'señales'-. Al no tener la aptitud ni la voluntad para vivir lo absurdo, manifestando su incapacidad por medio de la queja y la autocompasión, el suicidio es su único camino. Se resigna al destino que su condición infeliz de mortal y el adulterio materno supuestamente le han prescrito y lo hace efectivo.

Otra figura mítica, no nombrada por su apelativo, aunque sí descrita claramente por el narrador, es Proteo, dios multiforme quien cambia constantemente su aspecto a voluntad para que nadie lo atrape. El narrador se dibuja y se borra, se define como un permanente boceto y deposita su atractivo "[...] en el cambio constante. Mi singular verdad resplandece en las múltiples facetas de lo falso [...]" (36). Su falta de originalidad reside en que sigue la moda y es, por lo tanto, un producto de la cultura. Igual que el texto, al ser virtual, "libre de toda anatomía" $(37)^{43}$, puede realizar sus múltiples transformaciones, de modo que puede ser todos... o ninguno. Por eso, como "criatura de la noche" se compara con un vampiro, es un "party-animal" y su ansiedad ante el paso del tiempo y su rechazo a la vejez lo asemejan a Peter Pan, entre otros álter ego.

Desde la intertextualidad literaria, el cuento de Edgar Allan Poe (1809-1849) "La Máscara de la Muerte Roja" (1842), lectura favorita de Willi en la tercera parte del relato, es determinante y permite otros paralelismos adicionales. Su protagonista, el Príncipe Próspero 
-como doble del narrador-Willi quien se aisla de los demás- huye de la muerte encerrándose en su castillo, donde realiza una fiesta de máscaras en compañía de su corte, mientras afuera la gente del pueblo muere atacada por la peste de la Muerte Roja. En el cuento de Fresán, el narrador se niega a amar otro hombre por no enfrentar a la sociedad y más tarde, por miedo a contagiarse de sida, envolviéndose en su soledad en medio de las fiestas. Al final del cuento de Poe, Próspero, recluido en "el cuarto negro" -última habitación del castillo y su propia habitación de los abrigos- muere alcanzado por la peste, luego de que uno a uno los invitados a la fiesta han muerto; así, los party-animals mueren por el sida -la Muerte Roja- quedando sólo el narrador quien utiliza múltiples máscaras para ocultarse. Como recurso para sentirse menos solo y abandonado, inventa a un Willi quien también muere por el virus.

La aparición de la idea de un doble en la figura de Willi y la misma biografía de éste, podría leerse a la luz de la vida del escritor estadounidense Truman Capote ${ }^{44}$ (1924-1984), quien vive atormentado por el desamor y rechazo maternos, los cuales le imponen un sentimiento de soledad y abandono emocional que lo obligan a la búsqueda permanente del amor. Su existencia, como la de Willi, también es definida por una incansable participación en las fiestas de la clase adinerada. En su autobiografía titulada "Vueltas nocturnas. O cómo practican la sexualidad los gemelos siameses", comprendido en su libro de cuentos cortos Música para camaleones ${ }^{45}$, incluye la presencia de un gemelo imaginario con el cual comparte sus experiencias y donde confiesa "Soy alcohólico. Soy drogadicto. Soy homosexual. Soy un genio" (s.f.: 144). Excepto por la creencia en su genialidad, el perfil del personaje de Fresán se corresponde perfectamente con la descripción que de sí hace Capote, con quien presenta, además, otras coincidencias biográficas y como él, se suicida con una sobredosis de barbitúricos, a los sesenta años.

La construcción ficticia de Willi, supuesta pareja del narrador, convoca también la ficción concebida por el escritor inglés Williams Wilkie Collins ${ }^{46}$ (1824-1889), quien, aquejado por un doloroso padecimiento de gota se hace adicto al láudano, el cual le provoca terribles alucinaciones. Una de ellas lo acompaña siempre y es, según Collins, su doble a quien llama "Ghost Wilkie". El nombre del escritor y su doble tienen gran parecido con el Willi del cuento de Fresán, así como la confesión del narrador, en la última parte del relato de que Willi es él, donde da la señal definitiva a quien lee sobre el sentido de toda su historia:

\footnotetext{
Mi nombre es Willi y nunca nadie me amó y nunca amé a nadie. El amor era un virus y yo cometí el error de pensar que se trataba de un virus mortal. El amor es deporte de valientes y yo nunca me atreví a practicarlo, jamás me animé a regocijarme en mi verdadera naturaleza, en mi única posibilidad de ser feliz. Ahora todos están enfermos menos yo. La plaga ha ido dando cuenta de todos los invitados y me ha ignorado [...]. (57)
}

La voz narrativa se reconoce en la historia del Príncipe Próspero y la imposibilidad de huir de su destino. Como hombre invisible su historia "nunca fue" (56), de manera que lo narrado es una ficción dentro de la ficción, donde los mediapaisajes sostienen su mundo imaginario -un simulacro de realidad- en el cual ya no soporta estar. El Narrador-Sísifo rehúsa vivir con rebeldía y encuentra refugio en "[...] el suicidio, [...] higiénico y ordenado y previsible" (58). Las pastillas escogidas para ese fin le han ayudado a despertar "despacio y para siempre" (58). Durante esa etapa de lucidez que dura sólo una noche, la última de su vida, su narración -como un hilo de Ariadna- lo guía por el camino de regreso al principio, hasta su nacimiento, en un viaje que implica "[...] un profundo deseo de cambio interior. [...] testimonio de una insatisfacción que impele a la búsqueda y al descubrimiento de nuevos horizontes" (Chevalier 1995: 1066). Descubrimiento que lo lleva a convertir su biografía ficticia en algo positivo: 


\begin{abstract}
Como si el patético absurdo de haber imaginado a otro - para que ese otro me imaginara a mí como a mí me gustaría en realidad haber sido y nunca fui- ya no me pareciera la más triste de las cobardías sino, por el contrario, lo más parecido a una obra de arte, algo digno de ser comunicado y transmitido para que otros lo capten y lo disfruten y lo entiendan y alguien que inaugure y vele la suerte y el destino de mi leyenda. (58)
\end{abstract}

Por medio del encuentro entre su texto y quien lo lea, su vida servirá, de "confusa moraleja" (58). El epígrafe de Kafka: "La felicidad es estar con gente" del inicio del relato es paradójica, pues a pesar del bullicio y la compañía de la gente en las fiestas, el narrador nunca es feliz. No se ha atrevido a ser. Esto sólo lo logra en el último momento de la noche en que muere, que le brinda una "felicidad de postdata" (58), al poder decir por unos instantes que es, cuando ya está dejando de ser.

\title{
5. Señales percibidas (a modo de cierre)
}

A partir de un texto-collage, abigarrado de "señales" globalizadas, conformadoras del mediapaisaje que claramente ha ayudado a construir el paisaje íntimo de Willi -su biografía e identidad- el final deja claro que todo ha dado inicio a partir de la repetición de la pregunta esencial y eterna, no importa la época ni quién la efectúe: ¿quién soy yo?

Como el ficticio Willi, a quien le encanta la literatura y cree en sus "poderes curativos" (55), el narrador, también ficticio porque es el doble de Willi, construye un texto donde implanta una vida suya 'otra', por medio de cuya virtualidad intenta realizarse de acuerdo a su "verdadera naturaleza" (57) de hombre gay que tuvo miedo de amar. Su narración parte de una "historia que nunca fue" para escenificar la historia que es, en un juego de oposiciones entre el parecer y el ser que incluye la evolución de la figura del doble según la propuesta de Freud, cuando deja de funcionar como un "[...] asegurador de la supervivencia" para convertirse en un "[...] mensajero de la muerte" (1981: 2494). El constante desdoblamiento Narrador-Willi-Sísifo-Proteo-Próspero-Wilkie-Capote y demás máscaras y facetas que se suceden es ficcional, literario y al contrario de Proteo, quien siempre logra escapar, la biografía del protagonista queda atrapada en el juego de cajas chinas que es el texto. La pregunta lanzada al espacio por los astronautas rusos perdidos ${ }^{47}$ es la misma del protagonista de este relatocollage "¿Hay alguien allí?” (60). Quien capte las señales podría responderlas.

\section{Notas}

1. El presente artículo es resultado parcial de la investigación, ya concluida, "La globalización y sus huellas en la narrativa breve latinoamericana de las dos últimas décadas", inscrita en la Vicerrectoría de Investigación de la Universidad de Costa Rica con el № 021-A9-173, de la cual resultó el artículo "De ciudades y pasiones. Un acercamiento a cuatro cuentos latinoamericanos del fin de siglo" (2010), en: Revista de Filología y Lingüística de la Universidad de Costa Rica ( $\left.{ }^{\circ} 36\right)$; así como los artículos "Memorias del desaliento. Acercamiento a dos cuentos cubanos contemporáneos: "Huracán" de Ena Lucía Portela y "La yerba atrae a los tiburones" de Michel Perdomo" (2012), en: Revista Estudios. Escuela de Estudios Generales de la Universidad de Costa Rica (N²5); y "Héroes sin futuro". Aproximación a "Deambulando por la orilla oscura" de Alberto Fuguet" (2012), en: Revista de Lenguas Modernas de la Universidad de Costa Rica $\left(\mathrm{N}^{\circ} 17\right)$.

2. Robertson (cfr. 2000) señala que los términos 'glocal' y 'glocalización' se han formado de la unión de las palabras global y local, y así es definido por el Diccionario Oxford de Nuevas Palabras (1991: 34). Esta misma fuente explica el origen del término en el concepto japonés dochakuka, derivado de dochaku, que significa "el que vive en su propia tierra". Se trata de un principio utilizado en Japón para hablar de 
la adaptación de técnicas agrarias a las condiciones locales de las tierras que se poseen y que luego se trasladó al ámbito japonés de los negocios, para referirse a una visión global adaptada a las condiciones locales. Un concepto que engloba la relación entre lo universal y lo particular, que según Robertson ha sido una preocupación histórica "casi obsesiva" en la cultura japonesa, ha pasado a ser utilizada mundialmente con el significado señalado. Es interesante apuntar que el término glocalización aún no aparece en el Diccionario de la Real Academia de la Lengua Española.

3. Dentro del término "media", " medios", "medios de comunicación de masas", "industrias de la comunicación" o "tecnologías de la comunicación" -los cuales son utilizados indistintamente por numerosos estudiosos- se incluyen la prensa escrita; la industria editorial; la radiodifusión; la televisión; la internet (la cibercomunicación: correo electrónico, foros de chat, blogs, etc.); la música y el cine, dirigidos a un público masivo. Daniel Mato insiste en que debido a las particularidades que presentan, habría que designar a cada una por separado, y ser llamadas: industria del cine, industria de la música, etc. (cfr. Mato 2005). En la actualidad tiene enorme importancia la multimedia que reúne texto, sonido, imagen, video, animación, juegos interactivos, etc., y es parte de las "industrias del entretenimiento" junto con el cine, la televisión, la música y los parques temáticos. Muy relacionado con todos ellos y fundamental para el estímulo del consumo, se encuentra la industria de la publicidad.

4. El destacado y las comillas son del texto original.

5. Los etnopaisajes definen el mundo en que vivimos a partir de una de sus características esenciales, que es el movimiento constante de personas a lo largo y ancho del planeta. Personas inmigrantes, turistas, refugiadas, exiliadas, en flujos que afectan notoriamente y de un modo nunca antes experimentado, la política de las naciones y las relaciones entre ellas, integrando lo global con lo local. El tecnopaisaje abarca la configuración global de toda la tecnología, la cual es regida por los flujos monetarios y las posibilidades políticas y laborales de los estados, moviéndose a alta velocidad y transpasando límites de toda índole, anteriormente impenetrables. El tercer aspecto, los finanzopaisajes, se refiere a la administración del capital global que es ahora aún más opaco y escurridizo (Appadurai 2002: 23).

6. $\quad$ El destacado es del texto original.

7. Tanto poder han acumulado los medios que se les ha llamado "el cuarto poder", en el sentido de que influyen de manera determinante en la toma de decisiones de los Estados. El término referido a la prensa escrita se le adjudica al escritor y político de origen angloirlandés Edmundo Burke (1729-1797), quien claramente reconoció el poder que el manejo de la información daría a los dueños de los periódicos. Actualmente se reconoce que otros medios, como la televisión e internet son más poderosos.

8. Publicado en la antología de cuentos McOndo. 1996. Alberto Fuguet y Sergio Gómez (Eds.). Barcelona: Mondadori.

9. Rodrigo Fresán nació en Argentina en1963; es escritor y periodista. Vive en Barcelona desde 1999 y trabaja en la Editorial Random House-Mondadori en la dirección de la colección de literatura criminal Roja \& Negra. Sus obras incluyen: Historia argentina (1991), Vidas de santos (1993), Trabajos manuales (1994), Esperanto (1995), La velocidad de las cosas (1998), Mantra (2001), Jardines de Kensington (2003) y El fondo del cielo (2009). Muchos de sus cuentos han aparecido en diferentes antologías internacionales y su obra ha sido traducida a varios idiomas. Es un escritor que constantemente corrige y aumenta su obra ya publicada, lo cual se considera una de sus características.

10. El "macondismo" es un relato de la identidad que según Erna von der Walde se ha [...] originado en América Latina como forma para hablar de nosotros mismos en relación, contraste u oposición a las miradas "occidentales", el macondismo aparece para los latinoamericanos como la forma afirmativa de representar el "Otro" de los europeos y norteamericanos. Aparece como una nueva mirada que sustituye a la decimonónica y en la que el relato que sirve de base ha sido suministrado por la propia cultura latinoamericana. [...] El macondismo arrastra rezagos de la visión telúrica de la raza, llevada a la indolencia y al desorden por una naturaleza indomable. Se apropia del gesto europeo, supuestamente enalteciéndolo, para así dar razón del atraso con respecto de los países industrializados, remitiéndolo a una cosmovisión mágica, que postula " sus propias leyes y se sustrae a las lecturas racionalistas. A su manera, el macondismo otorga el sello de aprobación a la mirada euro-norteamericana, y legitimidad a las divisiones geopolíticas de Primer y Tercer Mundo" (1998: 218). Un ejemplo de esta posición se 
muestra en el discurso "La soledad de América Latina", por medio del cual el escritor colombiano Gabriel García Márquez aceptó el Premio Nobel de Literatura en 1982.

11. El tema de la posibilidad de la "representación", ha sido muy discutido por autores como Deleuze, Baudrillard, Spivak, Laclau y Mignolo. Spivak propone que hay que ir paso a paso considerando las condiciones de posibilidad y de imposibilidad de la representación, de modo que sea posible transformar cada vez más la imposibilidad en posibilidad (cfr. 1994). Es un tema controversial que no se considerá en este estudio.

12. "Señales captadas en el corazón de una fiesta" transcurre en Argentina, como se verá en los siguientes apartados.

13. Según el Diccionario de la Real Academia de la Lengua, la cultura Pop es una corriente artística de origen norteamericano (Consultado en línea).

14. Entrevista realizada para La Nación Line por María Sonia Cristoff, el 5 de agosto de 1998.

15. A partir de aquí todas las citas del texto de Fresán, tomadas de la edición de 1996, indicarán sólo el número de la página.

16. "Viaje a la semilla" es el conocido cuento del cubano Alejo Carpentier (1904-1980), escrito en 1944, donde se da una inversión del tiempo lineal y lógico de la narración ya que según Ana María Barrenechea: "[...] funciona la minuciosa descripción del proceso del tiempo en orden invertido, desde la muerte al nacimiento, en choque con el orden habitual no mencionado pero consabido" (Barrenechea 1972: 399).

17. Alusión al cuento de Edgar Allan Poe (1809-1849) "Manuscrito encontrado en una botella" publicado por primera vez en 1833 en el periódico Baltimore Saturday Visiter.

18. De acuerdo al Diccionario de la Real Academia Española (Consultado en línea).

19. Cantada por uno de los grupos estadounidenses que más influencia ha tenido en la música de la época: Velvet Underground. Fundado, entre otros, por el conocido guitarrista, cantante y compositor Lou Reed (1942), quien luego continuó una exitosa carrera como solista en diversos géneros de rock. La banda estuvo activa desde 1964 hasta 1973, y era manejada por el artista Andy Warhol. Entre sus integrantes, además de Reed han estado John Cale, Walter Powers, Sterling Morrison, Maureen Tucker, Angus McLise y Doug Yule. Entre 1990 y 1996 dieron varios conciertos.

20. Pieza musical cantada por el grupo británico The Kinks, el cual fue creado en 1956 por los hermanos Ray y Dave Davies, e integrado a lo largo del tiempo por otros miembros como Mick Avory y Pete Quaifey.

21. Canción compuesta y cantada por el artista estadounidense Randy Newman.

22. Del dúo británico Pet Shop Boys. Ver cita 30.

23. Escrita y cantada por la artista italiana Rafaella Carrá.

24. Ver cita 19 sobre canción "All tomorrow's parties".

25. Ver cita 20 sobre canción "Party line".

26. Dúo de "synth pop" británico fundado en 1981, compuesto por el vocalista Neil Francis (1954) y el tecladista y vocalista Christopher Sean Lowe (1959). Entre sus piezas más populares están: "It's a Sin", "Always in My Mind", "What I Have Done To Deserve This?" y "West End Girls".

27. Grupo muy popular entre 1974 hasta 1991, cuando se separan sus integrantes: David Byrne (1952) de origen escocés y criado en Canadá y Estados Unidos, Chris Frantz y Tina Weymouth, más tarde ingresa Jerry Harrison. Su música es innovadora y cubre el género de "Rock New Wave" y "Funk". David Byrne es mencionado específicamente en el cuento al comentar el narrador que ahora -en el presente del relato- sólo es escuchado porque en sus canciones habla de las fiestas de antes.

28. Cuarteto inglés muy famoso, fundado en Liverpool en 1960 e integrado por John Lennon (1940-1980), Paul McCartney (1942), George Harrison (1943-2001) y Ringo Starr (1940). Es considerada la banda más aclamada por la crítica en toda la historia de la música popular y la más exitosa desde un punto de vista comercial. Su canción mencionada en el cuento es "Helter Skelter".

29. La Guerra de las Malvinas es un conflicto bélico que enfrenta a la República Argentina contra Inglaterra por la soberanía sobre las islas Malvinas, Georgia del Sur y Sandwich del Sur, la cual es reclamada por la primera. La lucha se extiende entre el 2 de abril y el 14 de junio de 1982 con la derrota argentina, lo cual precipita la caída del gobierno militar. En la actualidad se ha revivido la disputa entre los dos países y 
Argentina lucha en el ámbito de los organismos que administran el Derecho Internacional en un intento por conseguir la devolución de su soberanía sobre la islas mencionadas.

30. "Left to My Own Devices" es una canción incluida en el álbum Introspective (1987-1988), donde se cuenta un día en la vida de un joven que no tiene obligaciones y sólo hace lo que desea.

31. De acuerdo al Diccionario de la Real Academia Española (Consultado en línea).

32. Ultima película en que actúa Orson Wells, se considera uno de sus mejores trabajos como actor.

33. Personaje del libro del inglés Lewis Carroll (1832-1898) Alicia en el país de las Maravillas (1865). El escritor alemán Günter Grass (1927) considera que en la historia de Carroll, el Gato aparece cuando se dan cuestionamientos sobre el sentido de la vida, ante los cuales siempre responde: "hacia adelante". Interpretación pertinente puesto que es la relación de la madre del protagonista con su amante disfrazado de Gato la que marca la vida de aquel, desde que recién comienza hasta el final, en una búsqueda degradada por respuestas sobre el significado que la vida podría tener.

34. Basada en la novela del mismo nombre, escrita por el estadounidense Horace McCoy (1897-1955) y publicada en 1935.

35. Estadounidense (1934-2008), también actúa en varias películas.

36. Cineasta estadounidense nacido en 1953 y conocido por sus películas independientes y en colaboración con directores europeos. Algunas de ellas son: Dead Man (1995), Coffee and Cigarettes (2003) y The limits of Control (2009).

37. Burton es un director de cine estadounidense, nacido en 1958 y residente en Inglaterra, cuyas películas de carácter surrealista, a menudo oscuras y con elementos góticos, pesentan personajes inadaptados. Algunos films entre su extensa filmografía son: Batman (1989), Edward Manos de Tijeras (1990), Ed Wood (1995), Charlie y la fábrica de chocolate (2005), Alicia en el país de las maravillas (2010), etc.

38. Comediante inglés (1925-1980) de excéntrica personalidad, alcanzó la fama internacional por la serie de películas de la Pantera Rosa. Se dice que en su vida privada era inseguro, violento y neurótico y su dependencia de las drogas le afectó su salud. Era proverbial su carencia de sentido de humor fuera de la pantalla.

39. Actor estadounidense (1920-1966), postulado varias veces al premio de mejor actor por su desempeño en películas como De aquí a la eternidad (1953) y Un lugar bajo el sol (1951). Murió por complicaciones debidas a su adicción al alcohol y las drogas.

40. Nacido en Estados Unidos (1925-1985) fue el actor de películas romáticas más admirado en su época de apogeo. El descubrimiento de que padecía de sida en julio de 1985 y su muerte por el virus en octubre de ese año, significó el reconocimiento de los alcances de la pandemia, así como el inicio de cierta concienciación sobre los efectos que la homofobia provoca en las vidas de las personas no heterosexuales, por el ocultamiento que los obliga a vivir.

41. El doble, del alemán doppelgänger, significa "el que camina al lado". Ha sido un tema constante en la literatura oral y escrita a lo largo de la historia. Robert Louis Stevenson (1850-1894) en Dr. Jekyll y Mr. Hyde y Edgar Allan Poe (1809-1849) en William Wilson lo trabajan brillantemente. En América Latina, Jorge Luis Borges (1899-1986) y Julio Cortázar (1914-1984) entre otros, destacan por los numerosos textos en que aparece este tema.

42. Hay muchas versiones diferentes, provenientes de diferentes épocas, que cuentan los crímenes de Sísifo que provocaron su castigo, indagación que no es pertinente para este trabajo. En lo que sí hay coincidencia es en el castigo recibido.

43. Es una frase tomada de la canción "Wild Wild Life" del escocés David Byrne, fundador y cantante del grupo estadounidense The Talking Heads. Ver cita 27.

44. Escritor y periodista desde una edad muy temprana, Truman Capote es conocido, primeramente, por su novela Desayuno en Tiffani’s (1958) llevada al cine por el director Blake Edwards en 1961. En 1966, con su conocida obra A sangre fría (1966) crea un nuevo género de narrativa de no ficción llamada también "novela real", donde une creación literaria con periodismo. Es llevada al cine en 1967 por el director y productor Richard Brooks. En 2005 bajo la dirección de Bennet Miller, se filma una película, titulada Truman Capote, donde se muestran algunos aspectos de su vida.

45. Consultada en línea. 
46. Collins fue un novelista, dramaturgo y autor de cuentos, muy popular en su época. Escribió 27 novelas, más de 60 relatos cortos, al menos 14 obras de teatro y más de 100 obras de no fícción. Es considerado uno de los creadores del género de la novela policíaca y su novelas La piedra lunar y La dama de blanco, en opinión de Borges, pertenencen a la estirpe de libros inolvidables, con lo cual concuerda el poeta T.S. Eliot (1888-1965), quien señala a La piedra lunar como la más perfecta novela policíaca escrita, mientras el poeta y crítico Charles Swinburne (1837-1909) la considera una obra maestra. Collins escribió varios textos con Charles Dickens (1812-1870), a quien le unió una gran amistad.

47. Captada en 1961 por unos radioaficionados italianos, los hermanos Judica Cordiglia.

\section{Bibliografía}

Appadurai, Arjun. 2002. "Disyunción y diferencia en la economía cultural global". Criterios. 33: $13-41$.

Billard, Henri. 2006. "Mc Ondo y el VIH Sida. De maldición mortal a la vicisitud vital". En: Ars homoerótica: escribir la sexualidad en las letras hispanas. Nicolas Balutet (Ed.). Paris: Publibook. 61-65.

Caamaño, Virginia. 2008. "Rumores del presente: revelaciones y pequeñas historias. Un acercamiento a "Santa Narcótica" de Cristina Civale y "El tibio atajo de la paz" de Naief Yehya". Revista de Lenguas Modernas. 8: 113-149.

2009. "Enfrentamientos y rebeliones en un microcosmos urbano: historias de ascensor". Revista de Lenguas Modernas. 11 (2): 75-120.

2010. "De ciudades y pasiones. Un acercamiento a cuatro cuentos latinoamericanos del fin de siglo". Revista de Filología y Lingüística. 36 (1): 35-75.

Camus, Albert. 2008. El mito de Sísifo. Madrid: Alianza.

Cuadra, Álvaro. 2003. De la Ciudad Letrada a la Ciudad Virtual. Santiago: LOM.

Chevalier, Jean y Alain Gheerbrant. 1995. Diccionario de símbolos. Barcelona: Herder.

Donoso, Pilar. 2009. Correr el tupido velo. Santiago: Alfaguara.

Eribon, Didier. 2001. Reflexiones sobre la cuestión gay. Barcelona: Anagrama.

Fresán, Rodrigo. 1996. "Señales captadas en el corazón de una fiesta". En: McOndo. Alberto Fuguet y Sergio Gómez (Eds.). Barcelona: Mondadori. 33-60.

2004. "Apuntes (y algunas notas al pie) para una teoría del estigma: páginas sueltas del posible diario de un casi ex joven escritor sudamericano". En: Palabra de América. Prólogo de Guillermo Cabrera Infante. Barcelona: Seix Barral. 47-74.

Foucault, Michel. 2000. El orden del discurso. Barcelona: Tusquets.

Freud, Sigmund. 1981. "Lo siniestro". En: Obras Completas. Tomo III. Madrid: Biblioteca Nueva.

Frith, Simon. 1996. "Música e identidad". En: Cuestiones de identidad cultural. Stuart Hall y Paul du Gay (Comps.). Buenos Aires: Amorrortu.

Frith, Simon, Will Straw y John Street. 2006. La otra historia del rock. Barcelona: Ma Non Troppo.

García Canclini, Néstor. 2009. Lectores, espectadores e internautas. Barcelona: Gedisa. 
Garibay, Ángel Ma. 1971. Mitología griega. Dioses y héroes. México: Porrúa.

Giddens, Anthony. 2000. Modernidad e identidad del yo. El yo y la sociedad en la épca contemporánea. Barcelona: Península.

2002. Consecuencias de la modernidad. Madrid: Alianza.

Iwasaki, Fernando. 2004. "No quiero que a mí me lean como a mis antepasados". En: Palabra de América. Prólogo de Guillermo Cabrera Infante. Barcelona: Seix Barral. 104-122.

López de la Vieja, Ma. Teresa. 2003. Etica y Literatura. Madrid: Tecnos.

Martín-Barbero, Jesús. 2002. "La globalización en clave cultural: una mirada latinoamericana”. Ponencia presentada en Globalisme et Pluralisme Colloque Internacional, Bogues, Montreal.

Noemí Voionmaa, Daniel. 2004. Leer la pobreza en América Latina: literatura y velocidad. Santiago: Cuarto Propio.

Pizarnik, Alejandra. 2007. La extracción de la piedra de la locura. Otros poemas. Madrid: Visor.

Robertson, Roland. 2000. "Glocalización: tiempo-espacio y homogeneidad-heterogeneidad”. Zona Abierta. 92-93: 213-24.

Sarlo, Beatriz. 1996. Instantáneas. Medios, ciudad y costumbres en el fin de siglo. Buenos Aires: Espasa Calpe/Ariel.

Walde, Erna von der. 1998. "Realismo mágico y poscolonialismo: construcciones del otro desde la otredad". En: Teorías sin disciplina. Latinoamericanismo, poscolonialidad y globalización en debate. Santiago Castro Gómez y Eduardo Mendieta (Coords). México: Porrúa. 207-231.

\section{Consultas en internet}

Capote, Truman. s.f. "Vueltas nocturnas. O cómo practican la sexualidad los gemelos siameses". En: Música para Camaleones. Recuperado de: Musica\%20para\%20camaleones(1.) doc-LibreOffice Writer. Consulta: 10 de febrero de 2011.

Diccionario de la Real Academia de la Lengua. http://buscon.rae.es/drael/

Entrevista de María Sonia Cristoff a Fresán para La Nacion Line, 5 de agosto de 1998. Recuperado de: http://www.literatura.org/Fresan/rfR2.html Consulta: 18 de julio de 2011.

García, Miguel. 2007. “El rock argentino en clave académica”. Recuperado de: http://webnueva. unvm.edu.ar/webs/congresomusical1/conferencias/03-Miguel_Garc\%C3\%ADa_ Equipo.pdf Consulta: 20 febrero de 2011.

Remedi, Gustavo. 2001. "Dialéctica de la Globalización: la mediación también es el mensaje”. Recuperado de: http://www.trincoll.edu/ gremedi/globalizacion.htm Consulta: 25 de enero 2011. 
